\title{
EFFECT OF BIOCHAR ON SOIL CADMIUM CONTENT AND CADMIUM UPTAKE OF COTTON (GOSSYPIUM HIRSUTUM L.) GROWN IN NORTHWESTERN CHINA
}

\author{
ZHU, Y. Q. - WANG, H. J. ${ }^{*}$ - Lv, X. - Song, J. H. - WANG, J. G. - TIAN, T. \\ Agricultural College, Shihezi University, Shihezi, Xinjiang 832003, China \\ (e-mail: shzuyongqizhu@hotmail.com-Y.Q Zhu; phone: +86-131-5040-7812) \\ *Corresponding author \\ e-mail:wanghaijiang@shzu.edu.cn; phone: +86-189-6382-7056 \\ (Received 27 $7^{\text {th }}$ May 2020; accepted $30^{\text {th }}$ Aug 2021)
}

\begin{abstract}
In order to investigate the effects of biochar on soil cadmium $(\mathrm{Cd})$ content in northwestern China, we used cotton (Gossypium hirsutum L.) straw charcoal in a 2-year experiment involving different doses of both biochars $(1.5 \%(\mathrm{C} 1)$ and $3 \%(\mathrm{C} 2))$ and $\mathrm{Cd}\left(1 \mathrm{mg} \cdot \mathrm{kg}^{-1}(\mathrm{H} 1), 2 \mathrm{mg} \cdot \mathrm{kg}^{-1}(\mathrm{H} 2)\right.$, and $4 \mathrm{mg} \cdot \mathrm{kg}^{-1}$ (H3)) in addition to the treatments, control plots were set up with no biochar application. We grew cotton (Gossypium hirsutum L.) in pots for each treatment and examined soil $\mathrm{pH}$, $\mathrm{Cd}$ forms, and $\mathrm{Cd}$ accumulations in aboveground plant organs. Compared to no added biochar, the addition of biochar significantly increased soil $\mathrm{pH}$, but there was no notable difference in soil $\mathrm{pH}$ between the $\mathrm{C} 1$ and $\mathrm{C} 2$ treatments. Biochar significantly decreased soil-available $\mathrm{Cd}$ with this effect increasing with higher biochar doses. The lowest amounts of soil-available $\mathrm{Cd}$ in all $\mathrm{Cd}$ treatments $(\mathrm{H} 0-\mathrm{H} 3)$, including the control, occurred later in the study, typically at 90 to 150 days post treatment. In the cotton (Gossypium hirsutum L.), Cd preferentially accumulated the most in leaves, then in stems, and then in bolls and the amount of $\mathrm{Cd}$ in cotton and soil-available $\mathrm{Cd}$ significantly correlated. The addition of biochar promoted the transformation of exchangeable and carbonate-bound $\mathrm{Cd}$ to organic matter-bound $\mathrm{Cd}$ at 30, 60, and 90 days, and the exchangeable and carbonate-bound $\mathrm{Cd}$ to $\mathrm{Fe}-\mathrm{Mn}$ oxide-bound $\mathrm{Cd}$ at 120 and 150 days. In conclusion, biochar addition decreases both $\mathrm{Cd}$ bioavailability and the accumulation of $\mathrm{Cd}$ in cotton (Gossypium hirsutum L.) aboveground organs.
\end{abstract}

Keywords: cotton straw biochar, soil $\mathrm{pH}, \mathrm{Cd}$ forms, $\mathrm{Cd}$ bioavailability

\section{Introduction}

Widely found in farmland soils, cadmium $(\mathrm{Cd})$ is a highly toxic heavy metal that biomagnifies through the food chain, thus ultimately endangering human health ( $\mathrm{Li}$ et al., 2010). Studies proved that metals such as copper, lead, zinc, cobalt, nickel, chromium, and mercury which have been considered as hazardous heavy metals are very toxic elements (Ghassabzadeh et al., 2010). Wastewater, fertilization, and irrigation using wastewater containing $\mathrm{Cd}$ are the main sources of $\mathrm{Cd}$ pollution in China's soils, contributing to both soil and water pollution in the Xinjiang area of northwest China, where chemical fertilizers containing $\mathrm{Cd}$ are used. Such repeated fertilization over many years often leads to an accumulation of heavy metals in the soil and unacceptable amounts of Cd have been found in Xinjiang soil (Wang et al., 2016). When subjected to $\mathrm{Cd}$ exposure, plants display shortened root length, decreased chlorophyll amount, and decreased fruit number (Renyuan et al., 2018).

Biochar, a charcoal with a pore structure, high aromatization, and high carbon amount (Aslam et al., 2017), is beneficial in agricultural and environmental contexts, especially since the use of biochar as a soil amendment may potentially help to mitigate global warming (Gaunt, 2008), improve soil quality (Fellet et al., 2011), reduce the bioavailability of organic contaminants ( $\mathrm{Li}$ et al., 2010), and increase nutrient and water 
retention capacity of soil (Abel et al., 2013; Zheng et al., 2013), thereby increasing crop yield (Zhang et al., 2013). Song et al. (2017) showed that modified walnut shell biochar is a catalyst for the catalytic removal of organic sulfur and arsenic. Other research has shown that biochar decreases the mobility of heavy metals by altering soil $\mathrm{pH}$ to control heavy metal mobilization (Tong et al., 2020; Ma et al., 2020; Kim et al., 2015; Zhu et al., 2015). Also, Zhu et al. (2015) demonstrated that $0.5 \%$ wine lees-derived biochar decreased exchangeable $\mathrm{Cd}$ in soil by $48.14 \%$ and Wang et al. (2016) showed that biochar derived from tea branches promoted the growth of Lolium multiflorum and reduced antimony and $\mathrm{Cd}$ bioavailability.

Cotton (Gossypium hirsutum L.), a dominant commercial crop in Xinjiang, was planted in $53.46 \%$ of the farmed area and provided $67.3 \%$ of the total Chinese cotton harvest (Gaunt, 2008). Long-term, continuous cotton cropping, coupled with the use of agricultural chemicals, have enriched Xinjiang farm soils with heavy metals. Luckily, abundant cotton straw accumulation, common in this large, cultivated area, presents an important opportunity to reduce soil pollution by converting it into biochar and using it as a soil amendment. Therefore, using heavy metal contaminated cotton stalks converted to biochar to both absorb $\mathrm{Cd}$ and provide nutrition in cotton field soil would not only reduce the risk of $\mathrm{Cd}$ contaminating farmland, but would also usefully reuse Cd-contaminated cotton stalks.

We applied cotton straw biochar to Cd-contaminated, Xinjiang, cotton field soil to examine the effects of biochar on various soil $\mathrm{Cd}$ forms and how $\mathrm{Cd}$ levels in soil varied over time, as well as cotton's absorption of $\mathrm{Cd}$ and how it varied over time. Our results provide basic data and technical reference for controlling $\mathrm{Cd}$ pollution in northwestern China farmland soil.

\section{Materials and methods}

\section{Soil and biochar collection and their physicochemical properties}

We conducted our experiments at the Agricultural College of Shihezi University in Shihezi City, Xinjiang Province, China $\left(86^{\circ} 03^{\prime} \mathrm{E}, 45^{\circ} 19^{\prime} \mathrm{N}\right)$ for a two-year continuous remediation. The temperate was of continental climate, with an average annual temperature of $7.5 \sim 8.2^{\circ} \mathrm{C}$, sunshine duration of $2318 \sim 2732 \mathrm{~h}$, frost-free period of 147 $\sim 191 \mathrm{~d}$, annual rainfall of $180 \sim 270 \mathrm{~mm}$, and annual evaporation of $1000 \sim 1500 \mathrm{~mm}$. The heavy metals in the soil of this area come mostly from chemical fertilizers, agricultural chemicals such as pesticides, and long-term continuous cropping. To manage and control potential errors, we used pots filled with loamy soil from test station cotton fields, where cotton had been continuously planted for more than 25 years. Here, because of long-term continuous cropping, the soil had various levels of heavy metals. Before collecting the samples, the depth of the soil sampling was 0$20 \mathrm{~cm}$, we have prepared $800 \mathrm{~kg}$ of soil sample we removed soil debris by hand and then air dried the soil before passing it through a $2 \mathrm{~mm}$-mesh sieve, keeping a subsample to determine the soil's physicochemical characteristics. The hydrometer method was used to investigate soil particle size distribution, subsequently finding that the soil texture was clay loam (Bouyoucos, 1962), and then used the Walkley-Black method described by Nelson and Sommers (1982) to determine soil organic carbon. We used a soil-water suspension (w/v, 1:2.5), shaken for $1 \mathrm{~h}$, to measure soil $\mathrm{pH}$ using a calibrated pH meter (WTW 7110, Weilheim, Germany) (Muhammad, 2019). Total nitrogen (N), phosphorous $(\mathrm{P})$ and potassium $(\mathrm{K})$ concentrations were determined using the Kjeldahl 
protocol (Bremner and Mulvaney, 1982), the Watanabe and Olsen method (1965), and the $\mathrm{HF}_{-} \mathrm{HClO}_{4}-\mathrm{H}_{2} \mathrm{SO}_{4}$ digestion method (Page et al., 1982), respectively (Table 1).

Table 1. Basic physical-chemical properties of biochar and soil used in the experiments

\begin{tabular}{c|c|c}
\hline Property & Biochar & Soil \\
\hline $\mathrm{pH}$ & 9.50 & 7.76 \\
Total nitrogen $\left(\mathrm{g} \cdot \mathrm{kg}^{-1}\right)$ & 0.89 & 0.46 \\
Total $\mathrm{P}\left(\mathrm{g} \cdot \mathrm{kg}^{-1}\right)$ & 2.54 & 28.42 \\
Organic matter $\left(\mathrm{g} \cdot \mathrm{kg}^{-1}\right)$ & 625 & 14.73 \\
Total $\mathrm{K}\left(\mathrm{g} \cdot \mathrm{kg}^{-1}\right)$ & 8.62 & 246.83 \\
Total Cd $\left(\mathrm{mg} \cdot \mathrm{kg}^{-1}\right)$ & 0.021 & 0.25 \\
Total salinity $\left(\mathrm{g} \cdot \mathrm{kg}^{-1}\right)$ & - & 3.36 \\
Carboxyl $\left(\mathrm{mmol} \cdot \mathrm{g}^{-1}\right)$ & 0.20 & - \\
Lactone $\left(\mathrm{mmol} \cdot \mathrm{g}^{-1}\right)$ & 0.25 & - \\
Phenolic hydroxyl $\left(\mathrm{mmol} \cdot \mathrm{g}^{-1}\right)$ & 0.21 & - \\
\hline
\end{tabular}

Biochar was prepared using anaerobic pyrolysis of cotton straw at $450{ }^{\circ} \mathrm{C}$ for $6 \mathrm{~h}$, with a resultant biochar conversion rate of $37.5 \%$ (Parinda et al., 2016). That biochar was then dried, crushed, and screened through a 2-mm sieve and its $\mathrm{pH}$ was measured in a $10 \mathrm{mmol} \cdot \mathrm{L}^{-1} \mathrm{CaCl}_{2}$ solution (solid: solution $=1: 2.5(\mathrm{w} / \mathrm{v})$ ) using a glass electrode and a Corning $\mathrm{pH} 10$ portable $\mathrm{pH}$ meter (Acton, MA, USA). We used the same methods to determine total $\mathrm{N}$, total $\mathrm{P}$, total $\mathrm{K}$, and organic carbon concentration as we used for the soil (Table 1). Biochar pore structure is illustrated in Figure 1.
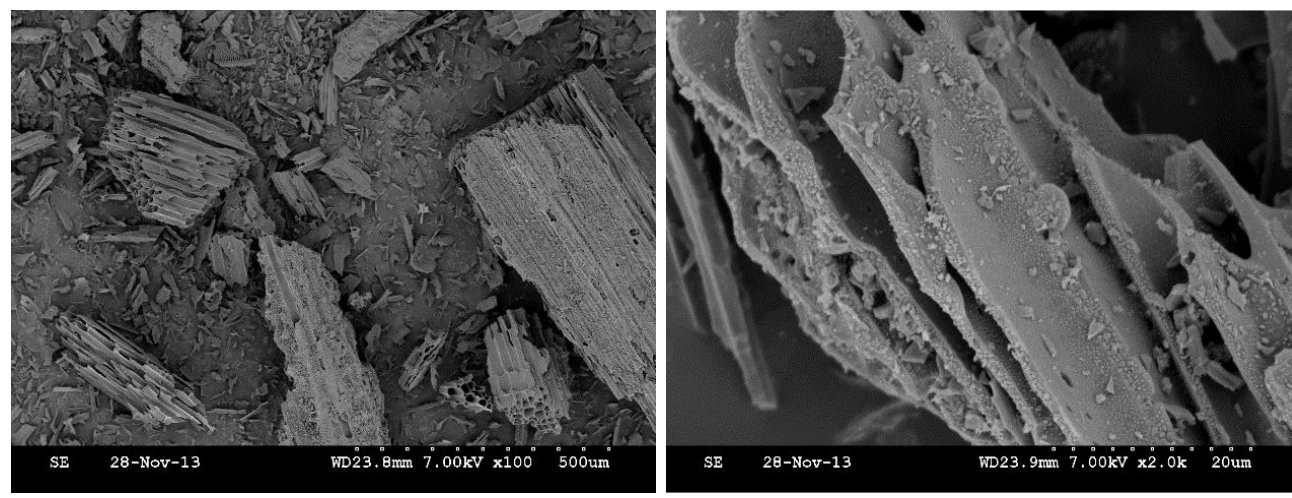

Figure 1. Representative microporous structure of biochar magnified $100 \times(500 \mu \mathrm{m}(\mathrm{left}))$ and $2,000 \times(20 \mu m(r i g h t))$

\section{Experiment pot design}

Before beginning the experiment, the soil was air dried and screened through a $2-\mathrm{mm}$ sieve. We prepared contaminated soil by first dissolving our $\mathrm{Cd}$ source, $\mathrm{CdCl}_{2} \cdot 2.5 \mathrm{H}_{2} \mathrm{O}$ (2.44 g, analytical reagent, Merck, Germany), in distilled water. We shook the preparation to ensure complete dissolution and then diluted it to $1000 \mathrm{~mL}$, resulting in a $1.2 \mathrm{~g} \cdot \mathrm{L}^{-1}$ solution of $\mathrm{Cd}^{2+} .10,20$, or $40 \mathrm{~mL}$ of that stock solution were each mixed with $12 \mathrm{~kg}$ soil samples, thus producing experimental samples with 1,2 , and $4 \mathrm{mg} \cdot \mathrm{kg}^{-1}$ exogenous $\mathrm{Cd}^{2+}$ amount levels. Those levels correspond to 1-, 2-, and 4-times China's 
Level III Soil Environmental Quality standard for Cd. Control soil with no added Cd and the 1,2 , and $4 \mathrm{mg} \cdot \mathrm{kg}^{-1} \mathrm{Cd}$ samples were named $\mathrm{H} 0, \mathrm{H} 1, \mathrm{H} 2$, and $\mathrm{H} 3$, respectively. Next, we used a plastic container and a spatula to mix biochar into the soil at $1.5 \%$ and $3 \% \mathrm{w} / \mathrm{w}$ (equivalent to $23.4 \mathrm{t} \cdot \mathrm{ha}^{-1}$ and $46.8 \mathrm{t} \cdot \mathrm{ha}^{-1}$ ), respectively. Biochar levels of $0 \%$, $1.5 \%$, and $3 \%$ (mass ratio) were named $\mathrm{C} 0, \mathrm{C} 1$, and $\mathrm{C} 2$, respectively. Finally, we made 12 experimental soil treatments by completely mixing either $\mathrm{H} 0, \mathrm{H} 1, \mathrm{H} 2$, or $\mathrm{H} 3 \mathrm{CdCl}_{2}$ soils with either $\mathrm{C} 0, \mathrm{C} 1$, or $\mathrm{C} 2$ biochar soils on a plastic cloth. For each experimental soil treatment, we put $12 \mathrm{~kg}$ of soil into a pot $(25 \mathrm{~cm} \times 30 \mathrm{~cm})$, repeating each treatment 5 times for a total of 60 pots. The pots were placed in a randomized block design and maintained in identical conditions for 10 weeks (Fig. 2). Each pot received recommended doses of $\mathrm{N}-\mathrm{P}_{2} \mathrm{O}_{2}-\mathrm{K}_{2} \mathrm{O} \quad\left(180-150-210 \mathrm{~kg} \cdot \mathrm{hm}^{2}\right.$ urea, diammonium phosphate, and potassium sulfate, respectively). All the $\mathrm{P}$ and $\mathrm{K}$ and half of the $\mathrm{N}$ was applied before crop sowing and the remaining $\mathrm{N}$ was applied after crop establishment.

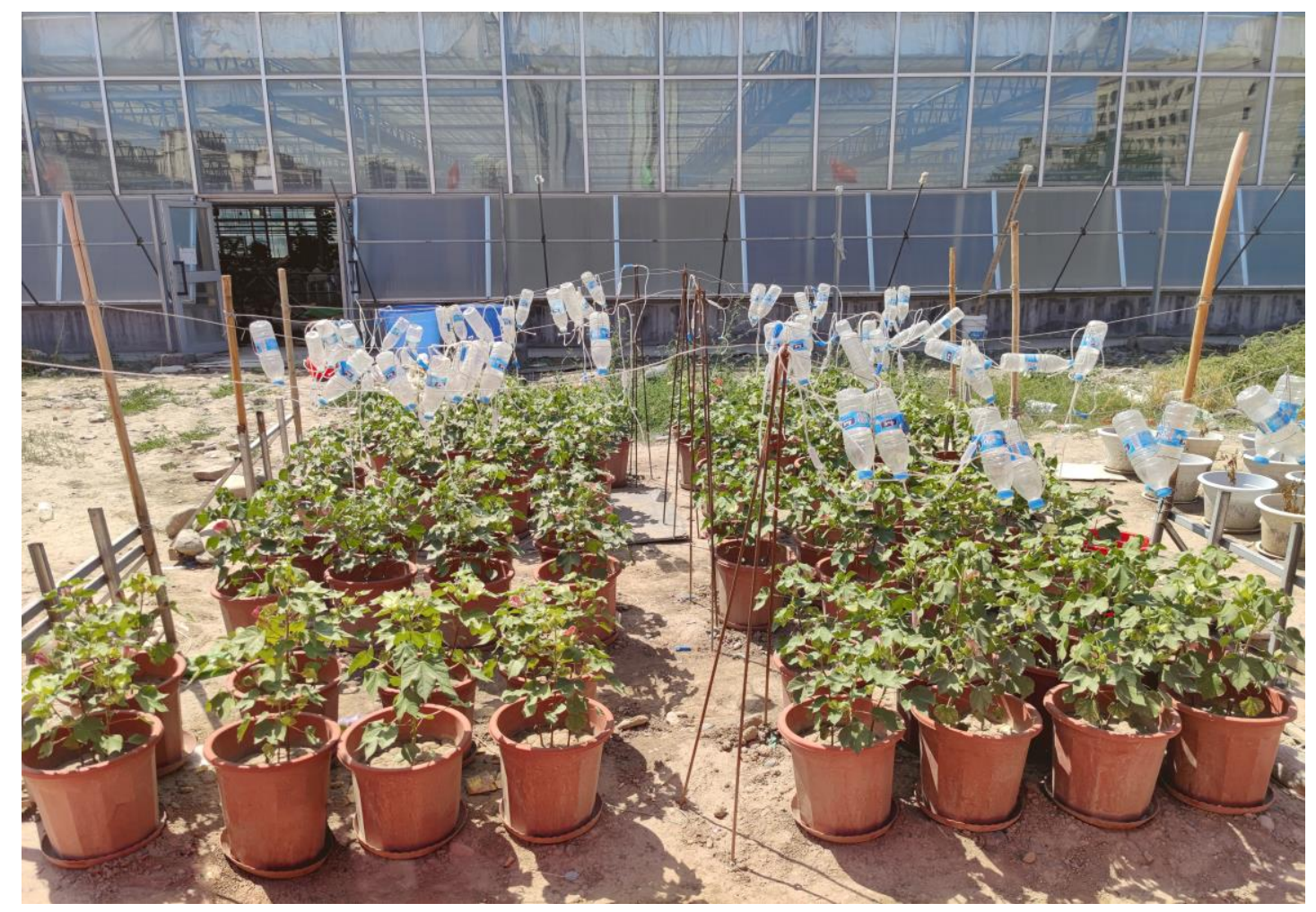

Figure 2. Pot culture experiment

\section{Planting and sample collection}

This study was conducted under open air. We first bought seeds of a local cotton variety (LuYan 24) and then disinfected and sterilized (with $2.5 \%$ sodium hypochlorite) same-sized seeds. Twenty seeds were planted in each plastic pot and, once they had 3-5 true leaves, seedlings were thinned to 5 per pot and grown for 150 days. To prevent recontamination, we use deionized water for irrigation. We collected soil and leaves and stems plant samples at 30,60, 90, 120, and 150 days of culture, and collected cotton bells at $60,90,120$, and 150 days of culture. Soil samples were collected by sampling 3 points in each pot to a maximum soil depth of $20 \mathrm{~cm}$, then the collected samples from each pot were combined and air-dried, the amount of the collected soil sample was 
180 g. Cotton stems, leaves, and bolls were collected and rinsed with deionized water and then weighed on a digital scale to determine each sample's wet weight, before they were oven dried $\left(85^{\circ} \mathrm{C}\right)$ to a constant dry weight.

\section{Tests and assays}

We used the Tessier 5 step continuous extraction method (Tessier et al., 1979) to sequentially extract trace metals, including $\mathrm{Cd}$, for subsequent measurement at the end of each step. Each $0.2000 \mathrm{~g}$ air-dried soil sample was subjected to the following operations, each designed to extract a fraction of the metals in the soil:

1. Exchangeable: Soil samples were oscillated continuously for $1 \mathrm{~h}$ with $1 \mathrm{~mol} \mathrm{~L}^{-1}$ $\mathrm{MgCl}_{2}$ solution $(\mathrm{pH}=7)$.

2. Bound to carbonates: The residue in step (1) was oscillated continuously for $5 \mathrm{~h}$ with $1 \mathrm{~mol} \cdot \mathrm{L}^{-1} \mathrm{CH}_{3} \mathrm{COONa}$ solution $(\mathrm{pH}=5)$.

3. Bound to iron $(\mathrm{Fe})$ and manganese $(\mathrm{Mn})$ oxides $(\mathrm{Fe}-\mathrm{MnO})$ : The residue in step (2) was oscillated continuously for $6 \mathrm{~h}$ at $96 \pm 3{ }^{\circ} \mathrm{C}$ with $0.04 \mathrm{~mol} \cdot \mathrm{L}^{-1}$ $\mathrm{NH}_{2} \mathrm{OH} \cdot \mathrm{HCl}$ diluted in $25 \%$ acetum solution.

4. Bound to organic matter: The residue in step (3) was oscillated for $2 \mathrm{~h}$ at $85 \pm 2$ ${ }^{\circ} \mathrm{C}$ with $3 \% \mathrm{H}_{2} \mathrm{O}_{2}$ (adjusted to $\mathrm{pH}=2$ using $\mathrm{HNO}_{3}$ ) and $0.02 \mathrm{~mol} \cdot \mathrm{L}^{-1} \mathrm{HNO}_{3}$ (volume ratio). Then $3 \% \mathrm{H}_{2} \mathrm{O}_{2}(\mathrm{pH}=2)$ was added, and the mixture was oscillated continuously for $3 \mathrm{~h}$ at $85 \pm 2{ }^{\circ} \mathrm{C}$. After cooling, the mixture was oscillated continuously for $0.5 \mathrm{~h}$ with $3.2 \mathrm{~mol} \cdot \mathrm{L}^{-1} \mathrm{CH}_{3} \mathrm{COONH}_{4}$ diluted in $20 \%$ $\mathrm{HNO}_{3}$ (volume ratio).

5. The residue form: Using the subtraction method, after the fractions from the previous 4 extractions were subtracted from the sample, the remaining amount was the residue.

Between each step, the mixture was centrifuged at room temperature for $15 \mathrm{~min}$ at $2000 \mathrm{rpm}$ and the supernatant was transferred into a $25 \mathrm{~mL}$ centrifugal tube to maintain constant volume. Then we used a Hitachi Z2000 graphite atomic absorption spectrophotometer (Hitachi, SiChuan., Tokyo, Japan) to detect metals in each supernatant sample.

We determined available $\mathrm{Cd}$ in the soil by performing diethyline-triamine-penta acetic acid extraction and then testing the extract with a graphite atomic absorption spectrophotometer (Mahanta et al., 2011). We then used microwave digestion-graphite atomic absorption spectrometry to determine $\mathrm{Cd}$ levels in the cotton stems, leaves, and bolls (Parinda et al., 2016). Soil $\mathrm{pH}$ was determined with the soil $\mathrm{pH}$-potential method, in which soil: water $=2.5: 1$ (Yan et al., 2000).

In addition, soil water content was determined gravimetrically by comparing the wet and dry weights of soil samples (collected at the end of every cotton growing stage) to determine the amount of soil irrigation (the field moisture capacity of 60\%-70\%) (Wang et al., 2020).

\section{Data analysis and visualization}

The data were compiled in Excel 2016 and two-way analysis of variance (ANOVA) was performed using SPSS 23.0. Multiple comparisons between different treatments were conducted using Duncan's new multiple range test $(\alpha=0.05)$. Charts were drawn using Origin 8.0 (OriginLab, MA, USA). 


\section{Results and analyses}

\section{Changes in soil $\mathrm{pH}$}

The addition of biochar significantly increased soil $\mathrm{pH}(P<0.05$, Table 2$)$, which rose in line with increasing biochar amounts. However, interactions between exogenous $\mathrm{Cd}$ and biochar had no significant effects on soil $\mathrm{pH}(P<0.05)$ and, as time elapsed, soil $\mathrm{pH}$ decreased. The maximum $\mathrm{pH}$ at 30 days was in the $\mathrm{C} 2 \mathrm{H} 3$ treatment $(\mathrm{pH}=8.56)$, thus showing that added biochar increased $\mathrm{pH}$ than those in the $\mathrm{C} 0$ treatments (controls, no biochar $(P<0.05)$. Overall, the experimental groups $\mathrm{pH}$ were higher than those of the control groups, but none of them were significantly different $(P<0.05)$. For instance, $\mathrm{pH}$ was not significantly different between the $\mathrm{C} 0 \mathrm{H} 0$ treatment and the $\mathrm{C} 1 \mathrm{H} 0$, $\mathrm{C} 1 \mathrm{H} 1$, and $\mathrm{C} 1 \mathrm{H} 3$ treatments after 150 days. After 30 days, the $\mathrm{COH}, \mathrm{COH} 1, \mathrm{COH} 2$, and $\mathrm{COH} 3$ treatments $\mathrm{pH}$ were $7.48,7.44,7.55$, and 7.49 , respectively, and this trend remained at $60,90,120$, and 150 days.

Table 2. Effects of biochar addition on soil $\mathrm{pH}$

\begin{tabular}{|c|c|c|c|c|c|c|}
\hline \multirow{2}{*}{$\begin{array}{c}\text { Cd content } \\
\left(\mathrm{mg} \cdot \mathrm{kg}^{-1}\right)\end{array}$} & \multirow{2}{*}{$\begin{array}{c}\text { Biochar } \\
(\%)\end{array}$} & \multicolumn{5}{|c|}{ pH } \\
\hline & & 30d & 60d & 90d & 120d & 150d \\
\hline \multirow{2}{*}{$\mathrm{H} 0$} & $\mathrm{CO}$ & $7.48 b$ & $7.66 b$ & $7.54 \mathrm{~b}$ & $7.35 b$ & $7.12 b$ \\
\hline & $\mathrm{C} 1$ & $8.46 \mathrm{a}$ & $8.24 \mathrm{a}$ & $8.09 a$ & $7.99 a$ & $7.46 \mathrm{~b}$ \\
\hline \multirow{4}{*}{$\mathrm{H} 1$} & $\mathrm{C} 2$ & $8.49 \mathrm{a}$ & $8.25 \mathrm{a}$ & $8.28 \mathrm{a}$ & $8.16 \mathrm{a}$ & $7.98 \mathrm{a}$ \\
\hline & $\mathrm{CO}$ & $7.44 b$ & $7.56 \mathrm{~b}$ & $7.35 b$ & $7.33 b$ & $7.33 b$ \\
\hline & $\mathrm{C} 1$ & $8.48 \mathrm{a}$ & $8.29 \mathrm{a}$ & $7.94 \mathrm{a}$ & $7.46 \mathrm{~b}$ & $7.46 \mathrm{~b}$ \\
\hline & $\mathrm{C} 2$ & $8.5 \mathrm{a}$ & $8.31 \mathrm{a}$ & $8.26 \mathrm{a}$ & $8.09 \mathrm{a}$ & $7.93 a$ \\
\hline \multirow{2}{*}{$\mathrm{H} 2$} & $\mathrm{CO}$ & $7.55 b$ & $7.58 \mathrm{~b}$ & $7.52 b$ & $7.35 b$ & $7.33 b$ \\
\hline & $\mathrm{C} 1$ & $8.51 \mathrm{a}$ & $8.32 \mathrm{a}$ & $8.24 \mathrm{a}$ & $7.92 \mathrm{a}$ & $7.63 \mathrm{ab}$ \\
\hline \multirow{4}{*}{$\mathrm{H} 3$} & $\mathrm{C} 2$ & $8.53 \mathrm{a}$ & $8.36 \mathrm{a}$ & $8.37 \mathrm{a}$ & $8.00 \mathrm{a}$ & $7.96 \mathrm{a}$ \\
\hline & $\mathrm{C} 0$ & $7.49 b$ & $7.43 b$ & $7.69 \mathrm{~b}$ & $7.34 \mathrm{~b}$ & $7.36 \mathrm{~b}$ \\
\hline & $\mathrm{C} 1$ & $8.44 \mathrm{a}$ & $8.44 a$ & $8.30 \mathrm{a}$ & $8.07 \mathrm{a}$ & $7.37 \mathrm{~b}$ \\
\hline & $\mathrm{C} 2$ & $8.56 \mathrm{a}$ & $8.49 \mathrm{a}$ & $8.27 \mathrm{a}$ & $8.19 \mathrm{a}$ & $8.03 \mathrm{a}$ \\
\hline \multicolumn{7}{|c|}{ Regression analysis (significance) } \\
\hline \multicolumn{2}{|c|}{ Cd content $(\mathrm{H})$} & $\mathrm{ns}$ & $\mathrm{ns}$ & $\mathrm{ns}$ & $\mathrm{ns}$ & $\mathrm{ns}$ \\
\hline \multicolumn{2}{|c|}{ Biochar $(\mathrm{C}$} & $* *$ & $* *$ & $* *$ & $* *$ & $* *$ \\
\hline \multicolumn{2}{|c|}{ Interaction $(\mathrm{H} \times \mathrm{C})$} & $\mathrm{ns}$ & ns & ns & $\mathrm{ns}$ & ns \\
\hline
\end{tabular}

$\mathrm{C} 0$, no added biochar; $\mathrm{C} 1,1.5 \%$ added biochar; $\mathrm{C} 2,3 \%$ added biochar; $\mathrm{H} 0$, no added $\mathrm{Cd}$; $\mathrm{H} 1,1 \mathrm{mg} \mathrm{kg}^{-1}$ $\mathrm{Cd}$ added; H2, $2 \mathrm{mg} \cdot \mathrm{kg}^{-1} \mathrm{Cd}$ added; H3, $4 \mathrm{mg} \cdot \mathrm{kg}^{-1} \mathrm{Cd}$ added. Different lowercase letters in the same column indicate significant differences $(P<0.05)$ in $\mathrm{pH}$ among individual treatments. $* *, P<0.01$; ns, $P \geq 0.05$

\section{Effects of biochar on Cd forms in the soil}

Throughout our sampling periods, $\mathrm{Cd}$ existed mostly as residue, accounting for $35.24 \%-63.02 \%$ of the total Cd (Fig. 3). Compared to C0 (no biochar), the biochar treatments exhibited reduced proportions of exchangeable and carbonate-bound $\mathrm{Cd}$. After 30 days, compared to the $\mathrm{COH} 0$ treatment, the proportion of exchangeable $\mathrm{Cd}$ decreased by $1.26 \%$ and $2.51 \%$ in the $\mathrm{C} 1 \mathrm{HO}$ and $\mathrm{C} 2 \mathrm{HO}$ treatments, respectively, and the proportion of carbonate-bound $\mathrm{Cd}$ decreased by $5.02 \%$ and $7.39 \%$ in the $\mathrm{C} 1 \mathrm{HO}$ and 
C2HO treatments, respectively, while organic-bound $\mathrm{Cd}$ increased by $11.57 \%$ and $15.21 \%$, respectively. This trend was the same in the $\mathrm{H} 1, \mathrm{H} 2$, and $\mathrm{H} 3$ groups (Fig. 3a). At 60 days, the proportion of exchangeable and carbonate-bound $\mathrm{Cd}$ in the $\mathrm{C} 1 \mathrm{H} 0$ and $\mathrm{C} 2 \mathrm{H} 0$ treatments decreased by $2.61 \%$ and $1.15 \%(\mathrm{C} 1 \mathrm{H} 0)$, and $3.38 \%$ and $6.74 \%$ $(\mathrm{C} 2 \mathrm{H} 0)$ respectively, as organic-bound $\mathrm{Cd}$ increased by $2.65 \%$ and $5.86 \%$, respectively in each treatment. Again $\mathrm{H} 1, \mathrm{H} 2$, and $\mathrm{H} 3$ trends for those tests mirrored these findings (Fig. 3b). The change of $\mathrm{Cd}$ forms after 90 days trended similarly to the 30 and 60-day results, indicating that biochar promoted the transformation of exchangeable and carbonate-bound $\mathrm{Cd}$ to organic-bound $\mathrm{Cd}$ (Fig. 3c). Figure $3 d$ and $e$ show changes of $\mathrm{Cd}$ forms in soils after 120 and 150 days, respectively. At the 120-day mark, the C1H0 and $\mathrm{C} 2 \mathrm{H} 0$ treatments had decreased proportions of exchangeable and carbonate-bound $\mathrm{Cd}(5.01 \%, 7.69 \%(\mathrm{C} 1 \mathrm{H} 0)$ and $2.37 \%, 5.52 \%(\mathrm{C} 2 \mathrm{H} 0)$, respectively) and increased proportions of Fe-Mn oxide-bound Cd (9.98\% and 18.07\%, respectively, Fig. 3d).

(a)

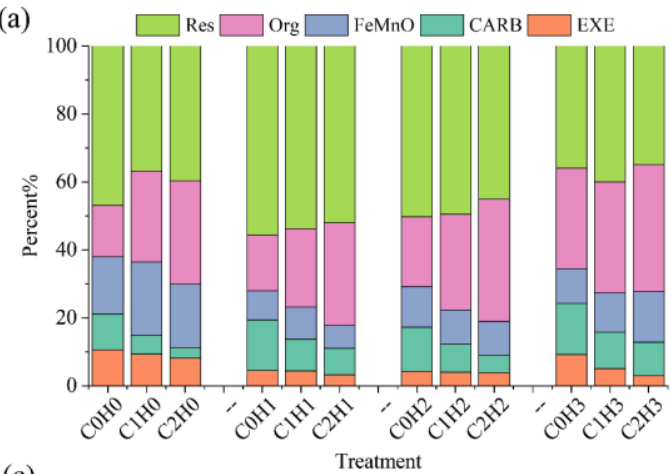

(c)

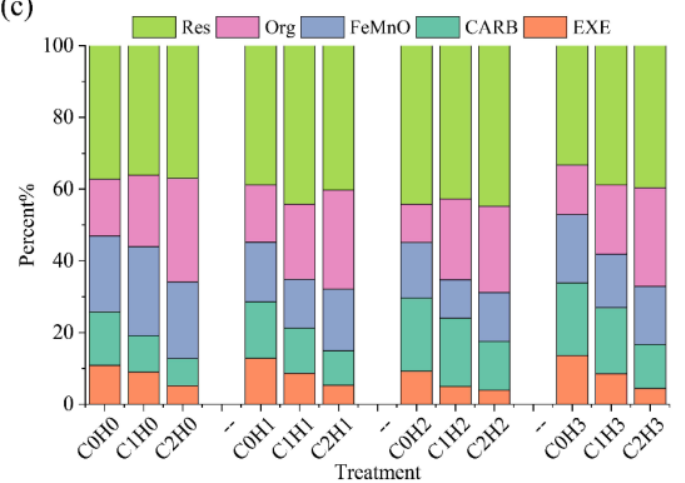

(b)

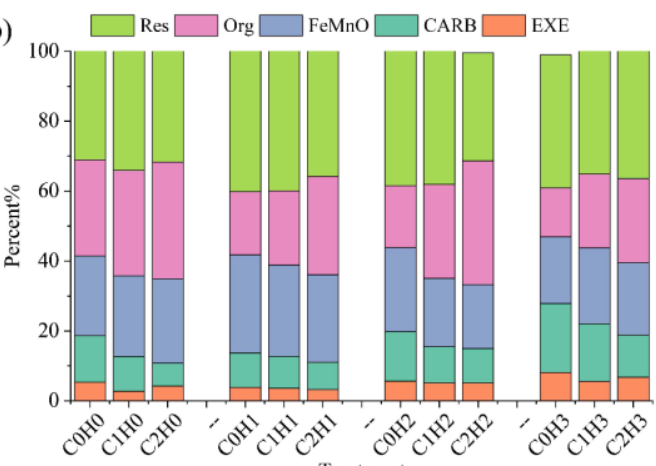

(d)

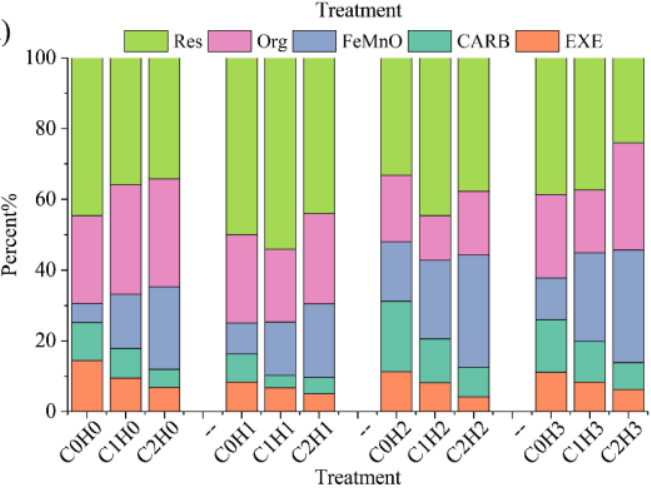

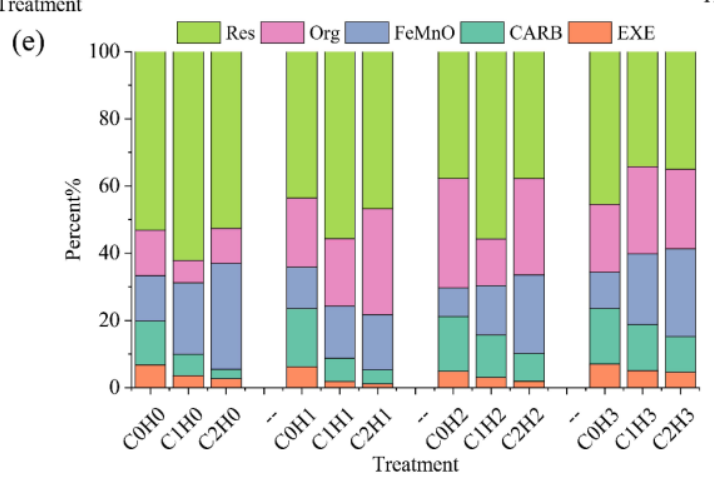

Figure 3. Effects of biochar on Cd distribution in the soil after 30 days (a), 60 days (b), 90 days (c), 120 days (d), and 150 days (e). Res, Cd residue; Org, fraction bound to organic matter;

$\mathrm{FeMnO}$, fraction bound to $\mathrm{Fe}-\mathrm{Mn}$ oxides; CARB, fraction bound to carbonates; EXE, exchangeable fraction; $C 0$, no added biochar; $C 1,1.5 \%$ added biochar; $C 2,3 \%$ added biochar; $\mathrm{HO}$, no added Cd; $\mathrm{Hl}, 1 \mathrm{mg} \cdot \mathrm{kg}^{-1} \mathrm{Cd}$ added; $\mathrm{H2}, 2 \mathrm{mg} \cdot \mathrm{kg}^{-1} \mathrm{Cd}$ added; $\mathrm{H3}, 4 \mathrm{mg} \cdot \mathrm{kg}^{-1} \mathrm{Cd}$ added 
This trend was similar in the $\mathrm{H} 1, \mathrm{H} 2$, and $\mathrm{H} 3$ groups, and for all treatments at 150 days (Fig. 3e) as well. So, after about 120 days of growth, exchangeable and carbonatebound $\mathrm{Cd}$ in biochar treated soils were being converted to $\mathrm{Fe}-\mathrm{Mn}$ oxide-bound $\mathrm{Cd}$, instead of to organic-bound $\mathrm{Cd}$, as was seen in earlier periods.

\section{Effects of biochar on available Cd}

In our study, the interaction of exogenous $\mathrm{Cd}$ with biochar significantly affected the amount of soil-available $\mathrm{Cd}$ (Table 3, $P<0.05$ ). Available $\mathrm{Cd}$ increased along with increasing exogenous $\mathrm{Cd}$ concentrations and, as time passed, the proportions of available $\mathrm{Cd}$ initially decreased and then stabilized. In the $\mathrm{COH}, \mathrm{COH} 1, \mathrm{COH} 2, \mathrm{COH} 3$ treatments, available $\mathrm{Cd}$ changed little over time, varying from $0.0002-0.0143 \mathrm{mg} \cdot \mathrm{kg}^{-1}$, while available $\mathrm{Cd}$ in the $\mathrm{C} 1$ and $\mathrm{C} 2$ groups differed significantly through time $(\mathrm{P}<0.05)$. The $\mathrm{COH} 0$ treatment had the least available $\mathrm{Cd}\left(0.0808 \mathrm{mg} \cdot \mathrm{kg}^{-1}\right)$ at 90 days, but it increased after that. The least available $\mathrm{Cd}$ in the $\mathrm{C} 1 \mathrm{H} 0$ treatment $\left(0.0702 \mathrm{mg} \mathrm{kg}^{-1}\right)$ was measured at 60 days and it stabilized after that, increasing to $0.0703 \mathrm{mg} \cdot \mathrm{kg}^{-1}$ at 150 days. At 90 days, the $\mathrm{C} 2 \mathrm{H} 0$ treatment had its lowest available Cd level $\left(0.1107 \mathrm{mg} \cdot \mathrm{kg}^{-1}\right)$, but that level later stabilized. So, available $\mathrm{Cd}$ in biochar treated soil without added $\mathrm{Cd}(\mathrm{C} 1 \mathrm{H} 0$ and $\mathrm{C} 2 \mathrm{H} 0)$ reduced significantly $(\mathrm{P}<0.05)$, but available $\mathrm{Cd}$ in the biochar treatments with the smallest amount of added $\mathrm{Cd}(\mathrm{C} 1 \mathrm{H} 1$ and $\mathrm{C} 2 \mathrm{H} 1)$ were lower than that in the $\mathrm{COH} 1$, no biochar/lowest added $\mathrm{Cd}$ treatment $(\mathrm{P}<0.05)$. The lowest $\mathrm{Cd}$ amount for $\mathrm{C} 1 \mathrm{H} 1$ $\left(0.1107 \mathrm{mg} \cdot \mathrm{kg}^{-1}\right)$ was measured at 90 days, while the lowest for C2H1 $\left(0.0819 \mathrm{mg} \cdot \mathrm{kg}^{-1}\right)$ was at 120 days. After reaching those minimum values, available $\mathrm{Cd}$ in both $\mathrm{C} 1 \mathrm{H} 1$ and $\mathrm{C} 2 \mathrm{H} 1$ stabilized and then decreased. In the $\mathrm{H} 2$ groups, available $\mathrm{Cd}$ in the $\mathrm{C} 1 \mathrm{H} 2$ and $\mathrm{C} 2 \mathrm{H} 2$ treatments was lowest at 120 days $\left(0.1732 \mathrm{mg} \cdot \mathrm{kg}^{-1}\right.$ and $0.1108 \mathrm{mg} \cdot \mathrm{kg}^{-1}$, respectively), Changes in available $\mathrm{Cd}$ in the $\mathrm{H} 3$ groups trended similarly to those in the $\mathrm{H} 2$ groups. Available $\mathrm{Cd}$ in the $\mathrm{C} 1 \mathrm{H} 3$ and $\mathrm{C} 2 \mathrm{H} 3$ treatments was significantly less than that in the $\mathrm{C} 0 \mathrm{H} 3$ treatment at 30, 60, 90, 120, 150 days. After 120 days, compared with $\mathrm{COH} 3$, available $\mathrm{Cd}$ in the $\mathrm{C} 2 \mathrm{H} 3$ treatment had decreased by $82.52 \%(\mathrm{P}<0.05)$.

\section{Effects of biochar on Cd amounts in cotton plants}

Biochar can reduce available $\mathrm{Cd}$ in soil by absorption, complexation, and precipitation, thus preventing cotton plants from absorbing Cd. Figures 4, 5, and 6 show that cotton leaves preferentially enrich in $\mathrm{Cd}$; however, after adding biochar, cotton's aboveground $\mathrm{Cd}$ uptake decreased. In the $\mathrm{C} 0 \mathrm{H} 0$ treatment, $\mathrm{Cd}$ uptake into cotton leaves, stems, and bolls increased from $0.0737,0.0144$, and $0.0103 \mathrm{mg} \cdot \mathrm{kg}^{-1}$ at 30 days to $0.0834,0.0151$, and $0.0114 \mathrm{mg} \cdot \mathrm{kg}^{-1}$ at 120 days, respectively, and then stabilized. We observed the same increasing trend in the other $\mathrm{H}$ groups. But Cd uptake in the $\mathrm{C} 1$ and $\mathrm{C} 2$ groups decreased as cultivation time increased. For example, Cd uptake into cotton leaves, stems, and bolls in the $\mathrm{C} 1 \mathrm{H} 3$ and $\mathrm{C} 2 \mathrm{H} 3$ treatments decreased between 30 days to 150 days $(\mathrm{P}<0.05)\left(\mathrm{C} 1 \mathrm{H} 3: 0.7414,0.0791\right.$, and $0.0538 \mathrm{mg} \cdot \mathrm{kg}^{-1}$ to $0.5822,0.0687$, and $0.0519 \mathrm{mg} \cdot \mathrm{kg}^{-1}$, respectively, and $\mathrm{C} 2 \mathrm{H} 3: 0.7049,0.0744$, and $0.0496 \mathrm{mg} \cdot \mathrm{kg}^{-1}$ to $0.5449,0.0621$, and $0.0471 \mathrm{mg} \cdot \mathrm{kg}^{-1}$, respectively). We observed a similar trend in the $\mathrm{C} 1 \mathrm{H} 1, \mathrm{C} 1 \mathrm{H} 2, \mathrm{C} 2 \mathrm{H} 1$, and $\mathrm{C} 2 \mathrm{H} 2$ treatments. In the $\mathrm{CIH} 0$ and $\mathrm{C} 2 \mathrm{H} 0$ treatments, the lowest uptake of $\mathrm{Cd}$ into cotton leaves $\left(0.0563 \mathrm{mg} \cdot \mathrm{kg}^{-1}\right.$ and $\left.0.0427 \mathrm{mg} \cdot \mathrm{kg}^{-1}\right)$, stems $\left(0.0129 \mathrm{mg} \cdot \mathrm{kg}^{-1}\right.$ and $\left.0.0113 \mathrm{mg} \cdot \mathrm{kg}^{-1}\right)$, and bolls $\left(0.009 \mathrm{mg} \cdot \mathrm{kg}^{-1}\right.$ and $\left.0.0078 \mathrm{mg} \cdot \mathrm{kg}^{-1}\right)$ occurred 90 days after biochar addition, corresponding to $30.58 \%, 49.28 \%, 15.69 \%$, $26.14 \%$, and $18.92 \%, 29.73 \%$ lower, respectively, than those of the C0 groups 
( $\mathrm{P}<0.05)$. At the $\mathrm{H} 1$ level, Cd uptake into cotton leaves, stems, and bolls after 90 days was the lowest in the $\mathrm{C} 1$ treatment $\left(0.1811,0.0339\right.$, and $0.0156 \mathrm{mg} \cdot \mathrm{kg}^{-1}$, respectively), which was $23.01 \%, 13.96 \%$, and $25.12 \%$ lower than in the $\mathrm{C} 0 \mathrm{H} 1$ treatment. However, $\mathrm{Cd}$ uptake into cotton leaves, stems, and bolls reached its lowest point in the $\mathrm{C} 2 \mathrm{H} 1$ treatment after 120 days $\left(0.1551,0.0300\right.$, and $\left.0.0141 \mathrm{mg} \cdot \mathrm{kg}^{-1}\right)$, which were $33.72 \%$, $26.11 \%$, and $32.86 \%$ lower than in the control groups. In the $\mathrm{CIHO}$ and $\mathrm{C} 2 \mathrm{HO}$ treatments, the lowest uptake of $\mathrm{Cd}$ into cotton leaves $\left(0.4197 \mathrm{mg} \cdot \mathrm{kg}^{-1}\right.$ and $\left.0.4034 \mathrm{mg} \cdot \mathrm{kg}^{-1}\right)$, stems $\left(0.0632 \mathrm{mg} \cdot \mathrm{kg}^{-1}\right.$ and $\left.0.0601 \mathrm{mg} \cdot \mathrm{kg}^{-1}\right)$, and bolls $\left(0.0385 \mathrm{mg} \cdot \mathrm{kg}^{-1}\right.$ and $0.0351 \mathrm{mg} \cdot \mathrm{kg}^{-1}$ ) decreased by $21.39 \%, 24.43 \%, 11.11 \%, 15.47 \%$ and $12.51 \%$, $20.23 \%$, respectively, then uptakes in the $\mathrm{COH} 2$ treatment occurred 90 days after biochar addition. The $\mathrm{H} 3$ uptakes trended similarly to $\mathrm{H} 2$, showing that biochar reduces the uptake of $\mathrm{Cd}$ by cotton, most likely through $\mathrm{Cd}$ adsorption.

Table 3. Effects of biochar on available Cd in the soil at different time points

\begin{tabular}{|c|c|c|c|c|c|c|}
\hline \multirow{2}{*}{$\begin{array}{l}\text { Cd content } \\
\left(\mathrm{mg} \cdot \mathrm{kg}^{-1}\right)\end{array}$} & \multirow{2}{*}{$\begin{array}{c}\text { Biochar } \\
(\%)\end{array}$} & \multicolumn{5}{|c|}{ Available Cd $\left(\mathrm{mg} \cdot \mathrm{kg}^{-1}\right)$} \\
\hline & & 30d & 60d & 90d & $120 d$ & 150d \\
\hline \multirow{3}{*}{$\mathrm{HO}$} & $\mathrm{CO}$ & $0.0934 \mathrm{a}$ & $0.0862 \mathrm{a}$ & $0.0808 \mathrm{a}$ & $0.0871 \mathrm{a}$ & $0.1016 \mathrm{a}$ \\
\hline & $\mathrm{C} 1$ & $0.0759 \mathrm{~b}$ & $0.0702 b$ & $0.0702 b$ & $0.0702 b$ & $0.0703 b$ \\
\hline & $\mathrm{C} 2$ & $0.0682 b$ & $0.0598 \mathrm{c}$ & $0.0439 \mathrm{c}$ & $0.0439 \mathrm{c}$ & $0.0439 c$ \\
\hline \multirow{3}{*}{$\mathrm{H} 1$} & $\mathrm{CO}$ & $0.1641 \mathrm{a}$ & $0.1573 a$ & $0.1518 \mathrm{a}$ & $0.1498 \mathrm{a}$ & $0.1493 a$ \\
\hline & $\mathrm{C} 1$ & $0.1340 \mathrm{~b}$ & $0.1242 b$ & $0.1107 \mathrm{~b}$ & $0.1107 \mathrm{~b}$ & $0.1108 b$ \\
\hline & $\mathrm{C} 2$ & $0.1087 \mathrm{c}$ & $0.0939 \mathrm{c}$ & $0.0896 \mathrm{c}$ & $0.0819 \mathrm{c}$ & $0.0819 \mathrm{c}$ \\
\hline \multirow{3}{*}{$\mathrm{H} 2$} & $\mathrm{CO}$ & $0.2285 \mathrm{a}$ & $0.2261 \mathrm{a}$ & $0.2303 \mathrm{a}$ & $0.2248 \mathrm{a}$ & $0.2239 a$ \\
\hline & $\mathrm{C} 1$ & $0.2051 b$ & $0.1935 b$ & $0.1761 b$ & $0.1732 b$ & $0.1733 b$ \\
\hline & $\mathrm{C} 2$ & $0.1513 \mathrm{c}$ & $0.1474 \mathrm{c}$ & $0.1260 \mathrm{c}$ & $0.1108 \mathrm{c}$ & $0.1107 \mathrm{c}$ \\
\hline \multirow{3}{*}{$\mathrm{H} 3$} & $\mathrm{CO}$ & $1.1145 \mathrm{a}$ & $1.1208 \mathrm{a}$ & $1.1194 \mathrm{a}$ & $1.1106 \mathrm{a}$ & $1.1138 \mathrm{a}$ \\
\hline & $\mathrm{C} 1$ & $0.8966 b$ & $0.8297 b$ & $0.8150 \mathrm{~b}$ & $0.793 b$ & $0.7931 b$ \\
\hline & $\mathrm{C} 2$ & $0.3952 \mathrm{c}$ & $0.3386 \mathrm{c}$ & $0.2195 c$ & $0.1959 \mathrm{c}$ & $0.1958 \mathrm{c}$ \\
\hline \multicolumn{7}{|c|}{ Regression analysis (significance) } \\
\hline Cd content $(\mathrm{H})$ & & $* *$ & $* *$ & $* *$ & $* *$ & $* *$ \\
\hline $\operatorname{Biochar}(\mathrm{C})$ & & $* *$ & $* *$ & $* *$ & $* *$ & $* *$ \\
\hline Interaction $(\mathrm{H} \times \mathrm{C})$ & & $* *$ & $* *$ & $* *$ & $* *$ & $* *$ \\
\hline
\end{tabular}

$\mathrm{H} 0$, no added $\mathrm{Cd}$; $\mathrm{H} 1,1 \mathrm{mg} \cdot \mathrm{kg}^{-1} \mathrm{Cd}$ added; $\mathrm{H} 2,2 \mathrm{mg} \cdot \mathrm{kg}^{-1} \mathrm{Cd}$ added; $\mathrm{H} 3,4 \mathrm{mg} \cdot \mathrm{kg}^{-1} \mathrm{Cd}$ added; $\mathrm{C}$, no added biochar; $\mathrm{C} 1,1.5 \%$ added biochar; $\mathrm{C} 2,3 \%$ added biochar; Different lowercase letters in the same column indicate significant differences $(P<0.05)$ in $\mathrm{pH}$ among individual treatments. **, $P<0.01$

\section{Correlations between soil pH, Cd forms, and Cd amounts in cotton}

$\mathrm{Cd}$ amounts in cotton leaves and stems were significantly correlated with $\mathrm{Cd}$ amounts in the soil ( $r=0.977$ and 0.915 , respectively; $P<0.01)$ and $\mathrm{Cd}$ amounts in cotton leaves, stems, was positively correlated with the amounts of exchangeable and available $\mathrm{Cd}$ in the soil (Table 4). However, $\mathrm{Cd}$ amounts in cotton leaves, stems, and bolls was significantly negatively correlated with the organic-bound $\mathrm{Cd}$ amount in the soil $(r=-0.633,-0.608$, and -0.968 , respectively; $(P<0.01))$, as were $\mathrm{pH}$ with the amounts of available, exchangeable, and carbonate-bound $\mathrm{Cd}$ in the soil $(r=-0.66$, - 
0.543 , and -0.555 , respectively; $P<0.01)$. Total Cd correlated highly with all $\mathrm{Cd}$ forms, while available $\mathrm{Cd}$ also correlated highly with both exchangeable and carbonate-bound $\mathrm{Cd}$ forms $(r=0.943$ and 0.716 , respectively; $P<0.01)$. Fe-Mn oxide-bound $\mathrm{Cd}$ amounts were significantly correlated with organic-bound, but not with available, exchangeable, and carbonate-bound, $\mathrm{Cd}$ amounts.

Table 4. Relationships between soil pH, and Cd contents in the soil and in cotton samples

\begin{tabular}{c|c|c|c|c|c|c|c|c|c}
\hline Indicators & $\begin{array}{c}\text { Soil } \\
\mathbf{p H}\end{array}$ & $\begin{array}{c}\text { Soil } \\
\text { Cd }\end{array}$ & $\begin{array}{c}\text { Leaf } \\
\text { Cd }\end{array}$ & $\begin{array}{c}\text { Stem } \\
\text { Cd }\end{array}$ & $\begin{array}{c}\text { Available } \\
\text { Cd }\end{array}$ & EXE & CARB & FeMnO & Org \\
\hline Soil pH & 1 & & & & & & & & \\
Soil Cd & 0.138 & 1 & & & & & & & \\
Leaf Cd & -0.126 & $0.977^{* *}$ & 1 & & & & & & \\
Stem Cd & -0.139 & $0.915^{* *}$ & $0.973^{* *}$ & 1 & & & & & \\
Available Cd & $-0.66^{* *}$ & $0.892^{* *}$ & $0.797 * *$ & $0.688^{* *}$ & 1 & & & & \\
EXE & $-0.543^{* *}$ & $0.951^{* *}$ & $0.668^{* *}$ & $0.871^{* *}$ & $0.943^{* *}$ & 1 & & & \\
CARB & $-0.555^{* *}$ & $0.821^{* *}$ & 0.211 & 0.174 & $0.716^{* *}$ & $0.815^{* *}$ & 1 & & \\
FeMnO & 0.244 & $-0.642^{* *}$ & -0.265 & -0.254 & -0.225 & -0.191 & -0.208 & 1 & \\
Org & 0.254 & $-0.778^{* *}$ & $-0.633^{* *}$ & $-0.608^{* *}$ & -0.240 & -0.238 & -0.209 & $0.304 *$ & 1 \\
\hline
\end{tabular}

Org, Cd fraction bound to organic matter; FeMnO, Cd fraction bound to Fe-Mn oxides; CARB, Cd fraction bound to carbonates; EXE, exchangeable fraction of Cd. **, $P<0.01 ; *, P<0.05$
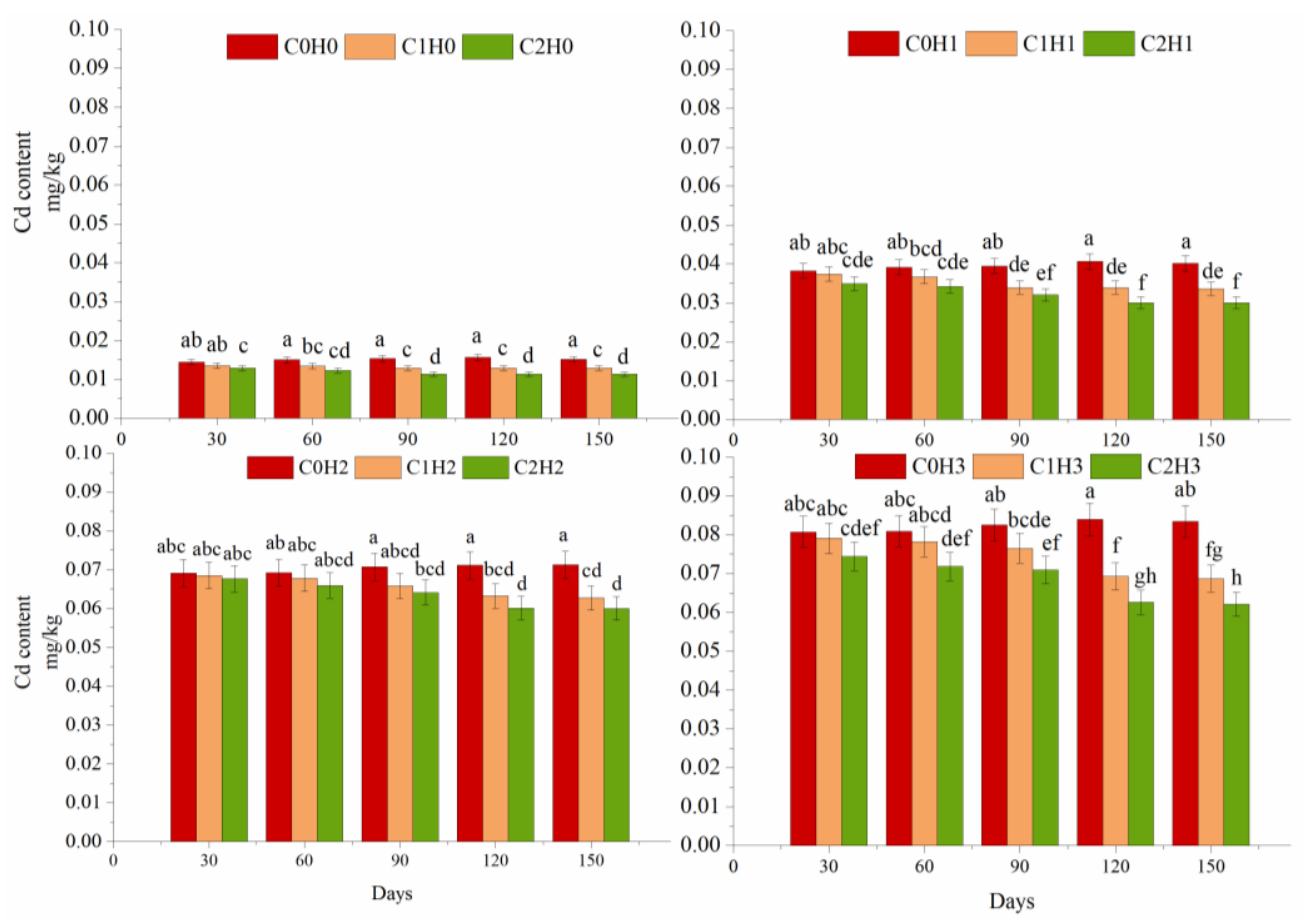

Figure 4. Effects of biochar on Cd contents in cotton leaves over time. CO, no added biochar; $\mathrm{Cl}, 1.5 \%$ added biochar; $\mathrm{C2}, 3 \%$ added biochar; $\mathrm{HO}$, no added $\mathrm{Cd} ; \mathrm{H1}, 1 \mathrm{mg} \cdot \mathrm{kg}^{-1} \mathrm{Cd}$ added; H2, $2 \mathrm{mg} \cdot \mathrm{kg}^{-1} \mathrm{Cd}$ added; H3, $4 \mathrm{mg} \cdot \mathrm{kg}^{-1} \mathrm{Cd}$ added. Error bars represent SD, Different letters within the same variety and column indicate significant difference at 0.05 level 


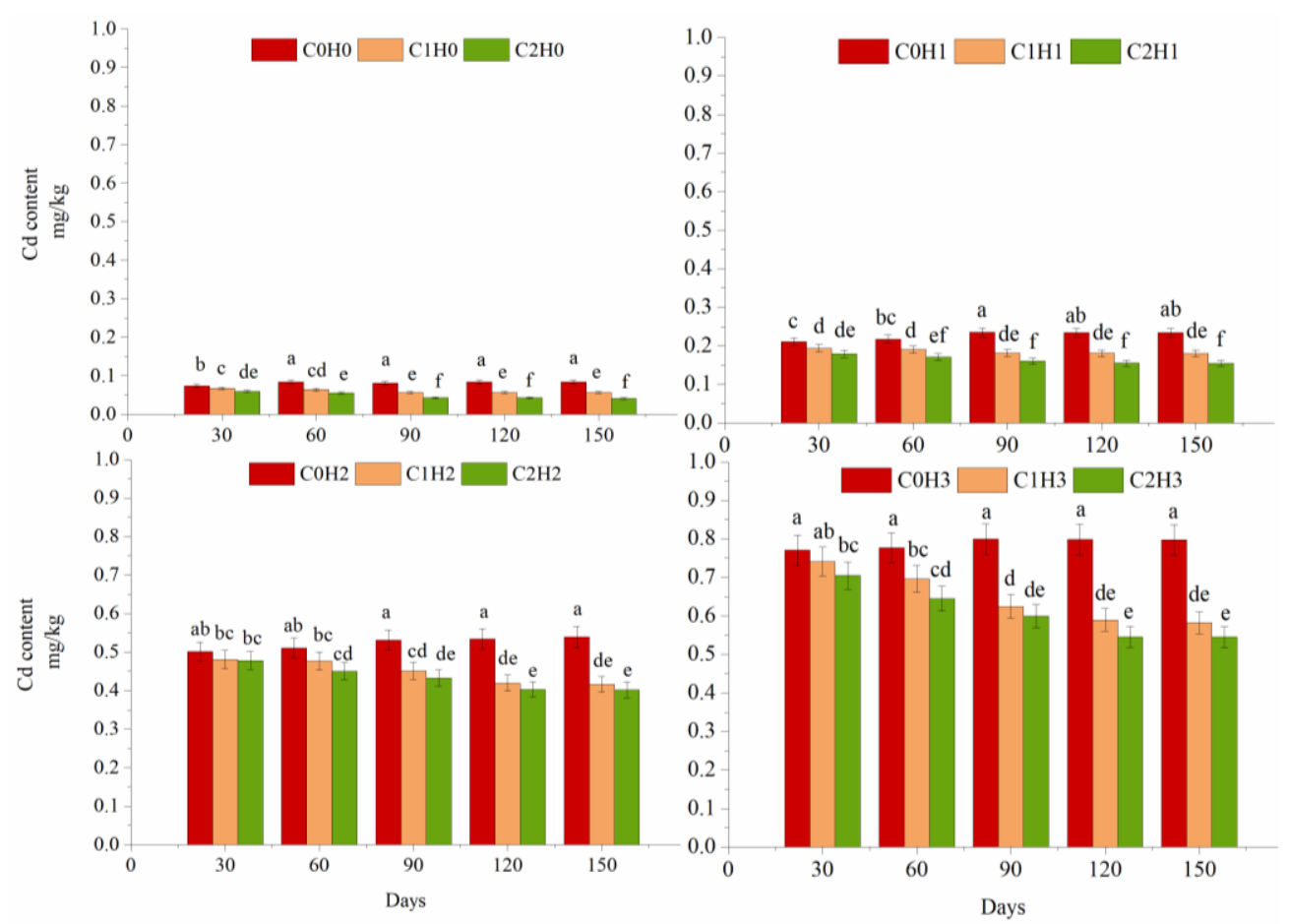

Figure 5. Effects of biochar on Cd contents in cotton stems over time. CO, no added biochar; $C 1,1.5 \%$ added biochar; $\mathrm{C2}, 3 \%$ added biochar; $\mathrm{HO}$, no added $\mathrm{Cd} ; \mathrm{H1}, 1 \mathrm{mg} \cdot \mathrm{kg}^{-1} \mathrm{Cd}$ added; $\mathrm{H2}, 2 \mathrm{mg} \cdot \mathrm{kg}^{-1} \mathrm{Cd}$ added; $\mathrm{H3}, 4 \mathrm{mg} \cdot \mathrm{kg}^{-1} \mathrm{Cd}$ added. Error bars represent SD, Different letters within the same variety and column indicate significant difference at 0.05 level
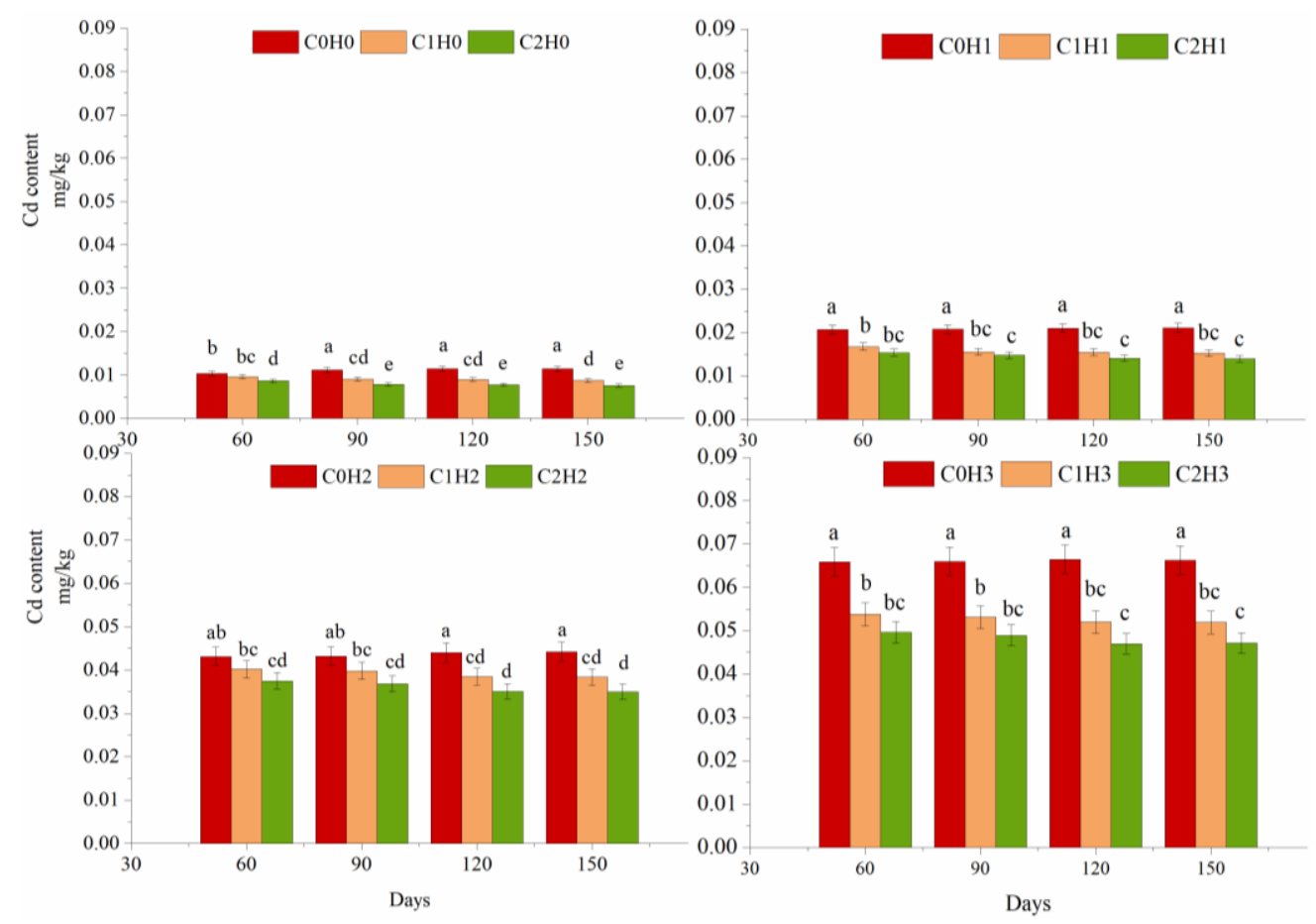

Figure 6. Effects of biochar on Cd content in cotton bolls over time. C0, no added biochar; $C 1$, 1.5\% added biochar; $\mathrm{C2}, 3 \%$ added biochar; $\mathrm{HO}$, no added $\mathrm{Cd} ; \mathrm{H1}, 1 \mathrm{mg} \cdot \mathrm{kg}^{-1} \mathrm{Cd}$ added; $\mathrm{H2}, 2$ $\mathrm{mg} \cdot \mathrm{kg}^{-1} \mathrm{Cd}$ added; H3, $4 \mathrm{mg} \cdot \mathrm{kg}^{-1} \mathrm{Cd}$ added. Error bars represent SD, Different letters within the same variety and column indicate significant difference at 0.05 level 


\section{Discussion}

Biochar has a rich microporous structure that forms a large specific surface area (Rehman et al., 2021; Ma et al., 2020; Eissa et al., 2019), and its ash contains much soluble calcium, magnesium, potassium, sodium, and other salt-based ions. Biochar added to soil improves the soil salt-based saturation to some extent as salt-based ions interact with both hydrogen and exchangeable aluminum ions. Within this ion-exchange interaction, soil $\mathrm{pH}$ increases as the amount of both hydrogen and aluminum ions decrease (Kookana et al., 2011). In our study, the addition of biochar significantly increased soil $\mathrm{pH}$, and $\mathrm{pH}$ increases paralleled increasing amounts of added biochar, peaking in the 3\% added biochar treatment (0.97-1.47 units relative to the blank). Guo et al. (2017) found that biochar promoted soil sediment formation $\left(\mathrm{CdCO}_{3}, \mathrm{Cu}(\mathrm{OH})_{2}\right.$, and $\left.\mathrm{Pb}_{5}\left(\mathrm{PO}_{4}\right)_{3} \mathrm{OH}\right)$ as soil $\mathrm{pH}$ increased, thereby reducing the soil $\mathrm{Cd}$ amount. In our study, biochar addition also reduced the amount of available $\mathrm{Cd}$ in the soil. The more biochar was added, the better the adsorption of soil $\mathrm{Cd}$ was. Without biochar and exogenous $\mathrm{Cd}$, soil $\mathrm{pH}$ initially increased but then decreased with time. Soil $\mathrm{pH}$ also initially increased and then decreased, finally stabilizing with the addition of exogenous $\mathrm{Cd}$ without biochar. Irrigation affects the process of soil reduction, ultimately resulting in the consumption of $\mathrm{H}^{+}$ions with an accompanying rapid soil $\mathrm{pH}$ increase. However, the combined effects of the resultant intermediate product (organic acid) and the final carbonate end product $\left(\mathrm{CO}_{2}\right)$ produced during watering causes a gradual decrease in soil pH over time (Yang et al., 2016; Cao et al., 2011).

Availability of heavy metals is an important indicator of heavy metal environmental behavior, and the addition of biochar can effectively reduce that availability. After 2 years, Bian et al. (2014) found that wheat straw biochar continuously reduced the available $\mathrm{Cd}$ in paddy soil. By increasing soil $\mathrm{pH}$, biochar promotes ion exchange on its surface (e.g., $\mathrm{Ca}^{2+}, \mathrm{K}^{+}$, and $\mathrm{Mg}^{2+}$ in the form of oxides or carbonates) and therefore reduces the mobility of exchangeable and carbonate-bound $\mathrm{Cd}$ in the soil (Aslam et al., 2017), an effect that increases along with increasing soil pH (Zhang et al., 2013; Kim et al., 2018). The adsorption of $\mathrm{Cd}$ to biochar also plays a non-negligible role in sequestering $\mathrm{Cd}$. In our study, available soil Cd initially decreased and then stabilized, as time passed. The extent of that reduction also differed between the different amounts of exogenous $\mathrm{Cd}$. With no exogenous $\mathrm{Cd}$, the available $\mathrm{Cd}$ in the soil decreased to its lowest level at 150 days, but $\mathrm{Cd}$ amounts in soil with $1 \mathrm{mg} \cdot \mathrm{kg}^{-1}$ added $\mathrm{Cd}^{2+}$ were the lowest after 120 and 150 days for treatments with $1.5 \%$ and $3 \%$ biochar, respectively. As exogenous $\mathrm{Cd}$ amounts increased $\left(2 \mathrm{mg} \cdot \mathrm{kg}^{-1} \mathrm{Cd}^{2+}\right.$ and $\left.4 \mathrm{mg} \cdot \mathrm{kg}^{-1} \mathrm{Cd}^{2+}\right)$, the treatments with $1.5 \%$ and $3 \%$ biochar experienced their lowest $\mathrm{Cd}$ amounts at 120 days. We found that the treatments with less added biochar and greater exogenous $\mathrm{Cd}$ reached equilibrium quicker than in other treatments, thus indicating that the ability of biochar to adsorb metals decreased over time (Bian et al., 2014). This stabilization at a later period, Kookana et al. (2010) called it "aging", in which natural organic molecules lead to the "aging" of biochar adsorption capacity, resulted in a balance of available Cd amount in soils (Xu et al., 2017; Mousavi et al., 2010).

Many studies have shown that exchangeable, carbonate-bound, and Fe-Mn oxides of heavy metals are available states and exhibit bioavailability under certain conditions. The effect of biochar on Cd form differs in different regions (Bashir et al., 2017). For example, Zhu et al. (2015) found that biochar decreased exchangeable $\mathrm{Cd}$ and increased Fe-Mn oxide-bound $\mathrm{Cd}$ in Shenyang paddy soil, while $\mathrm{Gu}$ et al. (2018) studied the transformation of $\mathrm{Cd}$ form in Hunan Province farmland soils and found that biochar 
decreased exchangeable $\mathrm{Cd}$ but increased both organic-bound and residual $\mathrm{Cd}$. Our results showed that, after biochar addition, the proportion of exchangeable and carbonate-bound $\mathrm{Cd}$ decreased; organic-bound $\mathrm{Cd}$ increased after 30, 60, and 90 days; and the proportion of exchangeable and carbonate-bound $\mathrm{Cd}$ decreased at 120 and 150 days, respectively, while the proportion of Fe-Mn oxide-bound $\mathrm{Cd}$ increased. The differing results of each study may be because of soil differences and the raw materials used to make biochar (e.g., different proportions of cellulose, hemicellulose, and lignin) between regions result in both inconsistent $\mathrm{Cd}$ speciation and effects of biochar on heavy metal Cd forms (Cantrell et al., 2012). However, when soil $\mathrm{pH}$ exceeds the zero charge of an $\mathrm{Fe}-\mathrm{MnO}$ colloid, the charge on the colloidal surface will change from positive to negative, thus increasing the Cd-adsorptive capacity of the colloid and possibly explaining the increase of Fe-Mn oxide-bound Cd (Neumann et al., 2001).

$\mathrm{Cd}$ is transported to aboveground plant organs via root absorption. Generally, after biochar addition the $\mathrm{Cd}$ amount in those organs decreased, but the effects of each biochar treatment on the accumulation of Cd differed (Zong et al., 2021). Abid et al. (2017) found that $\mathrm{Cd}$ amounts in tomato roots were 33\% lower than in the control when $1 \%$ biochar was added and Jin et al. (2011) showed that $\mathrm{Cd}$ amounts in Indian shepherd's purse buds were $76.1 \%, 82.2 \%$, and $96.3 \%$ lower than in the control when $1 \%, 5 \%$, and $15 \%$ chicken manure biochar, respectively, was added. In our study, biochar addition significantly reduced $\mathrm{Cd}$ accumulation in cotton, with the largest decrease occurring in the $\mathrm{C} 2 \mathrm{H} 3$ treatment (49.28\%) and resembling results were published by Rehman et al. (2021). The accumulation and distribution of heavy metals in plants depend on plant species, element species, chemical and biological availability, redox, $\mathrm{pH}$, cation exchange capacity, dissolved oxygen, temperature, and root secretions (Jin et al., 2011). Because of its large biomass, cotton has great tolerance to $\mathrm{Cd}$ and the accumulation of $\mathrm{Cd}$, but cotton seedling growth was inhibited when the exogenous soil $\mathrm{Cd}$ amount was $20 \mathrm{mg} \cdot \mathrm{L}^{-1}$. As their $\mathrm{Cd}$ amount increased from $20 \mathrm{mg} \cdot \mathrm{L}^{-1}$ to $80 \mathrm{mg} \cdot \mathrm{L}^{-1}$, the seedlings' stem and root lengths decreased significantly, but they still grew normally. Given this resilience, cotton is considered a good crop to grow for heavy metal remediation (Jin et al., 2011). Overall, our cotton exhibited good Cd absorption capacity, even without biochar, a result consistent with Ma et al. (2017). In our study, Cd primarily accumulated in cotton leaves, with a maximum uptake in the $\mathrm{COH} 3$ trial $\left(0.7992 \mathrm{mg} \cdot \mathrm{kg}^{-1}\right)$. Coincidentally, Cd uptake differed between different parts of various other crops, too. In pakchoi, $\mathrm{Cd}$ accumulated more in leaves than in roots and more in leaves than in petioles (Chen et al., 2012), but in maize and wheat, more $\mathrm{Cd}$ accumulated in leaves than in grain, and wheat grain enriched in $\mathrm{Cd}$ more than corn grain (Wang et al., 2017). In our study, Cd preferentially accumulated in leaves, then in stems and then in bolls. While soil $\mathrm{pH}$ did not correlate greatly with total $\mathrm{Cd}$, it did correlate significantly with available $\mathrm{Cd}$, primarily because biochar affected the distribution of heavy metal forms by affecting soil $\mathrm{pH}$ (Guo et al., 2017). That correlation showed that available $\mathrm{Cd}$ in soil could be directly absorbed by plants, resulting in a significant effect of available $\mathrm{Cd}$ on the $\mathrm{Cd}$ amount in cotton leaves and stems. Since biochar reduces the availability of soil $\mathrm{Cd}$, it most likely reduces the accumulation of heavy metals in the ground. 


\section{Conclusions}

Soil $\mathrm{pH}$ increased and available $\mathrm{Cd}$ decreased significantly with the addition of biochar, when the $\mathrm{Cd}$ dosage was $1 \mathrm{mg} \cdot \mathrm{kg}^{-1}$, available $\mathrm{Cd}$ in the $1.5 \%$ biochar treatment was the lowest at 120 days and at 150 days for the $3 \%$ biochar treatment. When $\mathrm{Cd}$ dosages were 2 and $4 \mathrm{mg} \cdot \mathrm{kg}^{-1}$, soil-available Cd reached minima at 120 days for both the $1.5 \%$ and $3 \%$ biochar treatments. Exchangeable $\mathrm{Cd}$ in the soil was the main source of accumulated $\mathrm{Cd}$ in aboveground plant organs. Biochar increased the proportion of organic-bound $\mathrm{Cd}$ (30, 60, and 90 days) and Fe-Mn oxide-bound $\mathrm{Cd}$ (120 and 150 days), then, biochar promoted the transformation of exchangeable and carbonatebound $\mathrm{Cd}$ to organic-bound and $\mathrm{Fe}-\mathrm{Mn}$ oxide-bound $\mathrm{Cd}$. Finally, biochar (1.5\% and $3 \%$ ) reduced soil available $\mathrm{Cd}$ content and slowed $\mathrm{Cd}$ uptake by cotton (Gossypium hirsutum L.). The physiological mechanism of biochar on Gossypium hirsutum L. growth promotion and Cd stress tolerance is not clear. The next step is to determine the effect of biochar on metabolism and metagenome of Gossypium hirsutum L. to determine the role of biochar under heavy metal stress.

Acknowledgments. This study was supported by the National Natural Science Foundation of China (Grant No. 31360301) and the International Cooperation Project of the Ministry of Science and Technology (2015DFA11660) and Major Science and Technology Project of the XPCC (2018AA004, 2018AA005, 2020AB018).

Conflict of interests. The authors declare that they have no conflict of interests.

\section{REFERENCES}

[1] Abel, S., Peters, A., Trinks, S., Schonsky, H., Facklam, M., Wessolek, G. (2013): Impact of biochar and hydrochar addition on water retention and water repellency of sandy soil. Geoderma 202-203: 183-191.

[2] Abid, M., Danish, S., Zafarulhye, M., Shaaban, M., Iqbal, M. M., Rehim, A. (2017): Biochar increased photosynthetic and accessory pigments in tomato (Solanum lycopersicum L.) plants by reducing cadmium concentration under various irrigation waters. - Environmental Science and Pollution Research International 1-8.

[3] Aslam, Z., Khalid, M., Naveed, M., Shahid, M. (2017): Evaluation of green waste and popular twigs biochar produced at different pyrolysis temperatures for remediation of heavy metals contaminated soil. - International Journal of Agriculture and Biology 19(6): 1427-1436.

[4] Bashir, S., Hussain, Q., Akmal, M., Riaz, M., Hu, H., Ijaz, S. S. (2017): Sugarcane bagasse-derived biochar reduces the cadmium and chromium bioavailability to mash bean and enhances the microbial activity in contaminated soil. - Journal of Soils and Sediments (3-4): 1-13.

[5] Bian, R., Joseph, S., Cui, L., Pan, G., Li, L., Liu, X. (2014): A three-year experiment confirms continuous immobilization of cadmium and lead in contaminated paddy field with biochar amendment. - Journal of Hazardous Materials 272(4): 121-128.

[6] Bouyoucos, G. J. (1962): Hydrometer method improved for making particle size analyses of soils1. - Agronomy Journal 54(5).

[7] Bremner, J. M., Mulvaney, C. S. (1982): Methods of Soil Analysis. Part 2. Agronomy. Vol. 9. 2nd Ed. - American Journal of Soil Science. Society, Madison, WI, pp. 595-624.

[8] Cantrell, K., Hunt, P., Uchimiya, M. (2012): Impact of pyrolysis temperature and manure source on physicochemical characteristics of biochar. - Bioresource Technology 107: 419-428. 
[9] Cao, X., Ma, L., Liang, Y., Gao, B., Harris, W. (2011): Simultaneous immobilization of lead and atrazine in contaminated soils using dairy-manure biochar. - Environmental Science and Technology 45(11): 4884-4889.

[10] Chen, Y., Li, T. Q., Han, X., Ding, Z. L., Yang, X. E., Jin, Y. F. (2012): Cadmium accumulation in different pakchoi cultivars and screening for pollution-safe cultivars. Journal of Zhejiang University-Science B 13(6): 494-502.

[11] Eissa, M. A. (2019): Effect of cow manure biochar on heavy metals uptake and translocation by zucchini (Cucurbita pepo L.). - Arabian Journal of Geosciences 12(2).

[12] Fellet, G., Marchiol, L., Delle Vedove, G., Peressotti, A. (2011): Application of biochar on mine tailings: effects and perspectives for land reclamation. - Chemosphere 83(9): 1262-1267.

[13] Gaunt, J. L., Lehmann, J. (2008): Energy balance and emissions associated with biochar sequestration and pyrolysis bioenergy production. - Environmental Science and Technology 42(11): 4152-4158.

[14] Ghassabzadeh, H., Torab-Mostaedi, M., Mohaddespour, A., Maragheh, M. G., Ahmadi, S. J., Zaheri, P. (2010): Characterizations of Co (II) and Pb (II) removal process from aqueous solutions using expanded perlite. - Desalination 261: 73-79.

[15] Gu, J. F., Zhou, H., Yang, W. T., Peng, P. Q., Zhang, P., Zeng, M. (2018): Effects of an additive (hydroxyapatite-biochar-zeolite) on the chemical speciation of cd and as in paddy soils and their accumulation and translocation in rice plants. - Environmental Science and Pollution Research (4): 1-12.

[16] Guo, X., Li, H., Chen, H. (2017): The effects of biochar and intercropping on the Cd, Cr and $\mathrm{Zn}$ speciation in soils and plant uptake by Machilus pauhoi. - Bulletin of Environmental Contamination and Toxicology 98(4): 1-8.

[17] Jin, H. P., Choppala, G. K., Bolan, N. S., Chung, J. W., Chuasavathi, T. (2011): Biochar reduces the bioavailability and phytotoxicity of heavy metals. - Plant and Soil 348(1/2): 439-451.

[18] Kim, H. S., Kim, K. R., Kim, H. J., Yoon, J. H., Yang, J. E., Yong, S. O. (2015): Effect of biochar on heavy metal immobilization and uptake by lettuce (Lactuca sativa, L.) in agricultural soil. - Environmental Earth Sciences 74(2): 1249-1259.

[19] Kim, H., Kim, J., Kim, M., Hyun, S., Moon, D. H. (2018): Sorption of sulfathiazole in the soil treated with giant miscanthus-derived biochar: effect of biochar pyrolysis temperature, soil $\mathrm{pH}$, and aging period. - Environmental Science and Pollution Research 25: 25681-25689.

[20] Kookana, R. S., Krull, E., Singh, B., Joseph, S. (2010): The role of biochar in modifying the environmental fate, bioavailability, and efficacy of pesticides in soils: a review. Australian Journal of Soil Research 48(7): 627-637.

[21] Kookana, R. S., Sarmah, A. K., Zwieten, L. V., Krull, E., Singh, B. (2011): Chapter three - Biochar application to soil: agronomic and environmental benefits and unintended consequences. - Advances in Agronomy 112: 103-143.

[22] Li, Z. Y., Tang, S. R., Deng, X. F., Wang, R. G., Song, Z. G. (2010): Contrasting effects of elevated $\mathrm{CO}_{2}$ on $\mathrm{Cu}$ and $\mathrm{Cd}$ uptake by different rice varieties grown on contaminated soils with two levels of metals: implication for phytoextraction and food safety. - Journal of Hazardous Materials 177(1-3): 352-361.

[23] Ma, X., Zheng, C., Li, W., Ai, S., Zhang, Z., Zhou, X. (2017): Potential use of cotton for remediating heavy metal-polluted soils in southern China. - Journal of Soils and Sediments 17: 2866-2872.

[24] Ma, X. L., Zhang, J., Yan, T. Y., Sun, J., Wang, J. H., Feng, J., Wang, H. B. (2020): Study on the cd (ii) adsorption characteristics of different saline-alkaline soils in western Jilin province, China. - Applied Ecology and Environmental Research 18(1): 315-329.

[25] Mahanta, M. J., Bhattacharyya, K. G. (2011): Total concentrations, fractionation and mobility of heavy metals in soils of urban area of Guwahati, India. - Environmental Monitoring and Assessment 173(1-4): 221-240. 
[26] Mousavi, H. Z., Hosseinifar, A., Jahed, V. (2010): Removal of Cu(ii) from wastewater by waste tire rubber ash. - Journal of the Serbian Chemical Society 75(6): 845-853.

[27] Muhammad, N., Siddiqua, S. (2019): Stabilization of silty sand using bentonitemagnesium-alkalinization: mechanical, physicochemical and microstructural characterization. - Applied Clay Science 183: 105325.

[28] Nelson, D. W., Sommers, L. E. (1982): Total Carbon, Organic Carbon and Organic Matter. - In: Page, A. L., Miller, R. H., Keeney, D. R. (eds.) Methods of Soil Analysis. American Society of Agronomy, Madison, WI, pp. 539-579.

[29] Neumann, D., Zur, N. U. (2001): Silicon and heavy metal tolerance of higher plants. Phytochemistry 56(7): 685-92.

[30] Page, A. L., Miller, R. H., Keeney, D. R. (1982): Methods of Soil Analysis. Part 2: Chemical and Microbiological Properties. - American Society of Agronomy Inc. and Soil Science Society of America Inc., Madison, WI.

[31] Parinda, S., Apinya, P., Prapai, D., Phenjun, M., Paitip, T. (2016): Effect of biochars and microorganisms on cadmium accumulation in rice grains grown in Cd-contaminated soil. - Environmental Science and Pollution Research 23(2): 962-973.

[32] Rehman, M. Z. U., Waqar, M., Bashir, S., Rizwan, M., Ali, S., El Baroudy, A. A. F., Khalid, H., Ayub, M. A., Usman, M., Jahan, S. (2021): Effect of biochar and compost on cadmium bioavailability and its uptake by wheat-rice cropping system irrigated with untreated sewage water: a field study. - Arabian Journal of Geosciences 14(2): 135.

[33] Renyuan, W., Mohammad, S., Jiawei, M., Bin, Z., Jia, G., Xiaowei, H. (2018): Effect of amendments on contaminated soil of multiple heavy metals and accumulation of heavy metals in plants. - Environmental Science and Pollution Research 25: 28695-28704.

[34] Song, X., Li, K., Wang, C., Sun, X., Ning, P., Tang, L. H. (2017): Regeneration performance and mechanism of modified walnut shell biochar catalyst for low temperature catalytic hydrolysis of organic sulfur. - Chemical Engineering Journal 330: 727-735.

[35] Tessier, A., Campbell, P. G. C., Bisson, M. (1979): Sequential extraction procedure for the speciation of particulate trace metals. - Analytical Chemistry 51(7): 844-851.

[36] Tong, W., Hamid, Y., Hussain, B., Usman, M., Sher, A., Liu, L., Yang, X. (2020): The effect of single and composite additives on cd and pb mobility, speciation and accumulation in late rice (Oryza sativa L.) grown on contaminated soil. - Applied Ecology and Environmental Research 18(3): 4207-4221.

[37] Wang, W., Lai, Y., Yuan, Y., Liu, Z., Wang, S., Hong, C. (2016): Heavy metal contamination of urban topsoil in a petrochemical industrial city in Xinjiang, China. Journal of Arid Land 8(6): 871-880.

[38] Wang, S., Wu, W., Liu, F., Liao, R., Hu, Y. (2017): Accumulation of heavy metals in soil-crop systems: a review for wheat and corn. - Environmental Science and Pollution Research International 24(2): 1-17.

[39] Wang, X. P., Wang, H. B., Si, Z. Y., Gao, Y., Duan, A. W. (2020): Modelling responses of cotton growth and yield to pre-planting soil moisture with the CROPGRO-Cotton model for a mulched drip irrigation system in the Tarim Basin. - Agricultural Water Management 241: 106378.

[40] Watanabe, F. S., Olsen, S. R. (1965): Test of an ascorbic acid method for determining phosphorus in water and $\mathrm{NaHCO}_{3}$ extracts from soil. - Soil Science Society of America Journal 29: 677-678.

[41] Xu, C., Chen, H. X., Xiang, Q., Zhu, H. H., Wang, S., Zhu, Q. H. (2017): Effect of peanut shell and wheat straw biochar on the availability of $\mathrm{cd}$ and $\mathrm{pb}$ in a soil-rice (Oryza sativa L.) system. - Environmental Science and Pollution Research 25(5): 1-10.

[42] Yan, A. M., Wang, E. T., Kan, F. L., Tan, Z. Y., Sui, X. H., Reinhold-Hurek, B., Chen, W. X. (2000): Sinorhizobium meliloti associated with Medicago sativa and Melilotus spp. in arid saline soils in Xinjiang, China. - Int $\mathrm{J}$ Syst Evol Microbiol. DOI: 10.1099/00207713-50-5-1887. 
[43] Yang, X., Liu, J., Mcgrouther, K., Huang, H., Lu, K., Guo, X. (2016): Effect of biochar on the extractability of heavy metals (cd, cu, pb, and $\mathrm{zn}$ ) and enzyme activity in soil. Environmental Science and Pollution Research 23(2): 974-984.

[44] Zhang, X., Wang, H., He, L., Lu, K., Sarmah, A., Li, J. (2013): Using biochar for remediation of soils contaminated with heavy metals and organic pollutants. Environmental Science \& Pollution Research 20(12): 8472-8483.

[45] Zheng, H., Wang, Z. Y., Deng, X., Herbert, S., Xing, B. S. (2013): Impacts of adding biochar on nitrogen retention and bioavailability in agricultural soil. - Geoderma 206: 3239.

[46] Zhu, Q., Wu, J., Wang, L., Yang, G., Zhang, X. (2015): Effect of biochar on heavy metal speciation of paddy soil. - Water Air and Soil Pollution 226(12): 1-10.

[47] Zong, Y. T., Xiao, Q., Malik, Z., Su, Y., Wang, Y. F., Lu, S. G. (2021): Crop strawderived biochar alleviated cadmium and copper phytotoxicity by reducing bioavailability and accumulation in a field experiment of rice-rape-corn rotation system. - Chemosphere 280: 130830. 